[Short Report]

\title{
A Preliminary Study on the Use of Meconium for the Assessment of Prenatal Exposure to Heavy Metals in Japan
}

\author{
Yeonsil YAng ${ }^{1}$, Satoshi NAKAI ${ }^{1, *}$, Shiori OdA ${ }^{2}$, Hiroko Nishino ${ }^{2}$, Misato IshiI ${ }^{3}$, Hiroko YoKoyAma ${ }^{3}$ and \\ Hideaki MATSUKI $^{3}$ \\ ${ }^{1}$ Graduate School of Environment and Information Sciences, Yokohama National University, Yokohama 240-8501, \\ Japan \\ ${ }^{2}$ Nursing Department, Tokai University Hospital, Isehara 259-1193, Japan \\ ${ }^{3}$ School of Health Sciences, Tokai University, Isehara 259-1193, Japan
}

\begin{abstract}
In recent years, there has been increasing interest in the relevance of environmental pollution to children's health. We investigated whether the concentrations of heavy metals in meconium can be used for the assessmet of prenatal exposure in Japan. Our study subjects were newborns whose mothers were hospitalized for childbirth at Tokai University Hospital between November 2010 and March 2011. The target compounds of this study were lead $(\mathrm{Pb})$, cadmium $(\mathrm{Cd})$ and arsenic $(\mathrm{As})$. Meconium samples collected from 102 newborns were analyzed using ICPMS. The median concentrations of $\mathrm{Pb}$ and $\mathrm{As}$ in the meconium were $0.71 \mathrm{ppb}$ and $0.03 \mathrm{ppb}$, respectively. The median concentration of $\mathrm{Cd}$ was below the limit of quantification. These concentration values are much lower than those used in previous studies. Further study is needed to compare the concentrations of heavy metals in biological samples and to investigate the availability of meconium for the assessment of exposure to heavy metals during pregnancy.
\end{abstract}

Keywords : children's health, prenatal exposure, meconium, heavy metals, newborn.

(Received March 11, 2013, accepted April 24, 2013)

\section{Introduction}

In recent years, there has been increasing interest in the relevance of environmental pollution to children's health. Environmental pollutants in soil, air, water, and food accumulate in the body through various routes, and children (including infants) and the elderly are considered as vulnerable groups to pollutants. As children grow day by day, they breathe more, eat more, and drink more water per unit of body weight than adults. It should be considered that poisons and/ or pollutants will have a much larger effect on their immature organs than on those of adults. The prena- tal period in particular is a time when the central nervous system is developing, and the fetus is sensitive to chemical exposure during the fetal stage. A pregnant mother's exposure to environmental pollutants could have a significant impact on her child $[1,2]$. It is important to investigate how children's development might be affected by fetal exposure to environmental pollutants.

Much research has been conducted on the health effects of environmental pollution on children, and in recent years various studies have focused on prenatal exposure. The National Children's Study (NCS) is a 21-year long cohort study being conducted on ap-

*Corresponding Author: Satoshi Nakai, Graduate School of Environment and Information Sciences, Yokohama National University, Japan. Tokiwadai, Hodogaya, Yokohama 240-8501, Japan. Tel: +81-45-339-4364, Fax: +81-45-339-4373, E-mail: snakai@ynu.ac.jp 
proximately 100,000 children that is investigating the interaction between genetic factors and environmental factors and their effects on pregnancy and childbirth, the health and development of children, and precursors of adult diseases [3]. The Children's Environment and Health Action Plan for Europe (CHHAPE), issued by the $\mathrm{EU}$, is a plan to reduce environmental exposure and prevent asthma, allergies, respiratory diseases, and congenital disorders [4]. In South Korea, the Mother and Children's Health and Environment (MOCHE) Study, which is a study to assess environmental exposure of children and pregnant women and their health, began in 2006 [5]. In Japan, the Ministry of the Environment launched a cohort study in 2011 (Japan Environment and Children's Study, JECS) to investigate the development of physical and mental health of children with prenatal exposure [6].

Exposure assessment should be important in the study of the relationship between exposure to chemical substances and health effects. Even though a number of exposure assessment studies have been conducted on children, there is not yet enough information about prenatal exposure. Thus far, heavy metal exposure assessments during the fetal period were carried out mainly using children's hair and cord blood. Collection, transportation and storage of hair are easy and inexpensive, and this method provides short-term and long-term exposure information. However, there are some disadvantages in that concentration is affected by hair color and ethnicity. It has also been pointed out that hair cannot be collected at birth [7]. Blood is considered an ideal biological sample for exposure assessment, but it has the disadvantage that it must be collected in an invasive way. Therefore, the use of blood as a biomarker should be restricted. There are also a few reported cases in Japan about the use of cord blood as a biomarker for environmental exposure. Although metal concentrations in cord blood can be interpreted as exposure, it is preferable to use other biomarkers when discussing health effects due to heavy metal contaminants. Exposure information for mother and child can be obtained from breast milk, and milk is often used to monitor information about exposure to fat-soluble chemicals. It is a non-invasive biological sample, but the measurement time is limited to the period of breastfeeding [8].
Meconium is the first, viscous, odorless and black feces discharged two to three days after birth. It can be used to examine cumulative prenatal exposure, because it is not excreted before birth. Meconium is usually discarded and can be collected non-invasively. Therefore, we can expect to easily get consent for sample acquisition, and to increase the number of samples as a result. While some studies to evaluate heavy metal exposure using meconium have been conducted in other countries $[1,9,10]$, there are no reports in Japan.

In this study, we examined the possibility of using meconium in Japan to measure prenatal exposure to low concentrations of heavy metals, and investigated the distribution of heavy metal concentrations in meconium, although the results are not at present linked to a discussion of health effects due to heavy metals.

Heavy metal contamination during pregnancy would be affected by the lifestyle and living habits of the mother. Higher concentrations of heavy metals have been observed with higher gestational age of the mother, and metal concentrations in mothers with a higher number of births can be lower [10, 11]. In addition, occupational exposure, residential area, lifestyle during pregnancy (medication, drinking, smoking, diet, etc.) have to be considered as important factors in exposure levels. Therefore, we also conducted a questionnaire survey and investigated the relevance of maternal lifestyle to the concentration of heavy metals in meconium.

\section{Methods}

\section{Subjects and data collection}

Our study subjects were newborns born at Tokai University Hospital (Isehara, Japan) between November 11, 2010 and March 11, 2011 and their mothers. We explained the purpose of the survey to each mother who was admitted to the hospital for childbirth and obtained written consent if she agreed to participate in the study.

A nurse collected meconium samples when changing diapers. If twins were born, meconium was collected from only one child, according to a request from the person in charge of the survey, in order to avoid any confusion in daily work. However, it is unclear which twin the meconium sample was taken from in this study. We also asked the mothers to fill out a 
questionnaire including questions such as height and weight of her newborn, daily lifestyle such as smoking and drinking, number of pregnancies, etc., at the time of discharge.

The ethics committees of Tokai University School of Medicine and Tokai University School of Health Sciences approved this study.

\section{Analysis}

Each meconium sample collected was stored at $-30^{\circ} \mathrm{C}$ in a vinyl bag with an identification code. In light of previous studies, we decided to examine the concentrations of arsenic (As), cadmium (Cd), and lead $(\mathrm{Pb})$ in the meconium.

An acid decomposition method based on Ostrea et al [1]. was used for pretreatment. The procedure we adopted was as follows: $70 \%$ nitric acid $(20 \mathrm{ml})$ was added to $0.1 \mathrm{~g}$ meconium, the sample was heated to dryness using a hot plate $\left(250^{\circ} \mathrm{C}\right), 5 \%$ nitric acid $(25$ $\mathrm{m} l$ ) was added to the sample and evaporated to $10 \mathrm{~m} l$ and then cooled, following which deionized water was added to make $50 \mathrm{~m} l$. Finally, we analyzed the sample using ICP-MS (Agilent $7700 \mathrm{x}$ ). The above pretreatment method cannot dry the sample completely. Therefore, in order to determine the dry weight, the same amount of sample was dried for 2 hours in an oven at $200^{\circ} \mathrm{C}$.

The limit of quantification (LOQ) and the detection limit were determined as ten times and three times the values of the standard deviation calculated from the analysis of seven blank samples, respectively. We also verified the measurement method by a recovery test in which a standard with a concentration approximately 10 times higher than the LOQ was used.

Finally, the distribution of heavy metal concentrations in the meconium with good recovery was described, and the relationships between the various factors and concentrations were examined.

\section{Results}

Meconium was collected from 108 infants during the period, but six infants were excluded from the analysis because of the small amount of their samples (less than $0.1 \mathrm{~g}$ ). Four sets of twins were born among the final 102 subject mothers.
The average age of the mothers was 34 years old, with a range of 22-43 years old, and the mean gestation period was 37.9 weeks. Seventeen mothers had experienced more than two pregnancies, and thirtyeight were housewives. Many of the subjects were living in the city of Yokohama, which is considered to have no problem with heavy metal environmental pollution. No subjects had job experience with occupational exposure to heavy metals.

Seventy-five persons were never smokers, and twenty-seven had quit smoking before getting pregnant. Eleven mothers were exposed to secondhand tobacco smoke during pregnancy, and their exposure time was less than 30 minutes a day on average. Three of the mothers drank alcohol during pregnancy.

Seventy-four mothers $(73 \%)$ consumed fish one to three times a week, sixty-eight ate shellfish one to three times a month, fifty-two had intake of dairy products daily, fifty-one had two rice meals a day, and forty-seven sometimes drank mineral water.

The mean ( \pm S.D) birth weight and height of the newborns was $2,864 \mathrm{~g} \pm 332 \mathrm{~g}$ and $48.0 \pm 1.9 \mathrm{~cm}$, respectively. Sixty-five babies were male (64\%).

The detection limits in this study were $0.008 \mathrm{ppb}$ for $\mathrm{Pb}, 0.006 \mathrm{ppb}$ for $\mathrm{Cd}$, and $0.007 \mathrm{ppb}$ for $\mathrm{As}$, and the LOQs were $0.027 \mathrm{ppb}, 0.019 \mathrm{ppb}$ and $0.022 \mathrm{ppb}$, respectively.

The average recovery for each metal was $109.5 \%$ for $\mathrm{Pb}$ (range: 81.5 to $145.1 \%$ ), $103.2 \%$ for $\mathrm{Cd}(79.0$ to $123.3 \%$ ), and $100.7 \%$ for As ( 87.6 to $111.9 \%$ ). It is thought that good recoveries were obtained for each heavy metal, and the measurements of all the metals are described below.

The average concentrations of $\mathrm{Pb}, \mathrm{Cd}$, and $\mathrm{As}$ ( \pm standard deviation) were $1.12 \mathrm{ppb} \pm 1.37 \mathrm{ppb}, 0.002 \mathrm{ppb} \pm$ $0.02 \mathrm{ppb}$ and $0.03 \mathrm{ppb} \pm 0.04 \mathrm{ppb}$, respectively. Since more than $90 \%$ of the $\mathrm{Cd}$ values were below the LOQ, the average value for Cd was less than the LOQ (Table 1). The median levels were $0.71 \mathrm{ppb}$ for $\mathrm{Pb}$, below the LOQ for $\mathrm{Cd}$, and $0.03 \mathrm{ppb}$ for As. The distribution of concentration for each metal had a right-skewed shape.

The rank correlation coefficients between the concentrations of heavy metals were 0.076 between $\mathrm{Pb}$ and $\mathrm{Cd},-0.06$ between $\mathrm{Pb}$ and $\mathrm{As}$, and -0.03 between $\mathrm{Cd}$ and As. No relationships were observed among the metals. 
Table 1. Heavy metal concentrations in meconium

\begin{tabular}{crcc}
\hline Metal & Mean \pm S.D. & Median $(25-75 \%)$ & Range $(\mathrm{ppb})$ \\
\hline $\mathrm{Pb}$ & $1.12 \pm 1.37$ & $0.71(0.29-1.28)$ & $<$ LOQ -6.91 \\
$\mathrm{Cd}$ & $<\mathrm{LOQ} \pm 0.02$ & $<\mathrm{LOQ}(<\mathrm{LOQ}-\mathrm{LOQ})$ & $<\mathrm{LOQ}-0.15$ \\
$\mathrm{As}$ & $0.03 \pm 0.04$ & $0.03(<\mathrm{LOQ}-0.05)$ & $<\mathrm{LOQ}-0.18$ \\
\hline
\end{tabular}

$\mathrm{n}=102, *<$ LOQ: calculated as zero level

Table 2 shows the concentration of heavy metals stratified by certain factors. Since most Cd concentrations were less than the LOQ, the stratified analysis for $\mathrm{Cd}$ was not conducted.

The median $\mathrm{Pb}$ concentration was $0.72 \mathrm{ppb}$ in mothers under 35 years old and $0.70 \mathrm{ppb}$ in mothers at least 35 years old. The median As level was $0.02 \mathrm{ppb}$ in mothers under 35 years old and 0.04 ppb in mothers at least 35 years old. There were no significant differences. There were also no significant differences in the concentration of heavy metals in the meconium by other factors such as child sex, number of pregnancies, smoking, or dietary intake of fish, selfish, dairy products or rice.

Table 2. Heavy metal concentrations stratified by maternal factors

\begin{tabular}{|c|c|c|}
\hline $\begin{array}{l}\text { Factor } \\
\text { (Number) }\end{array}$ & $\mathrm{Pb}$ & (ppb) \\
\hline \multicolumn{3}{|l|}{ Age } \\
\hline$<35$ yrs $(58)$ & $0.72(0.33-1.53)$ & $0.02\left(<\mathrm{LOQ}^{-0.04}\right)$ \\
\hline$\geq 35$ yrs (44) & $0.70(0.20-1.25)$ & $0.04\left(\begin{array}{ll}0.03 & -0.06\end{array}\right)$ \\
\hline \multicolumn{3}{|l|}{ Sex (newborn) } \\
\hline Male $\quad(65)$ & $0.74(0.30-1.46)$ & $0.03\left(<\mathrm{LOQ}^{-0.04}\right)$ \\
\hline Female (37) & $0.62(0.28-1.03)$ & $0.04(<\mathrm{LOQ}-0.06)$ \\
\hline \multicolumn{3}{|c|}{ No. of pregnancies } \\
\hline$<3(95)$ & $0.71(0.29-1.34)$ & $0.03(<\mathrm{LOQ}-0.05)$ \\
\hline$\geq 3(6)$ & $0.63(0.41-0.79)$ & $0.03(0.02-0.11)$ \\
\hline \multicolumn{3}{|c|}{ Current medication } \\
\hline Yes (37) & $0.68(0.27-1.35)$ & $0.03(<\mathrm{LOQ}-0.05)$ \\
\hline No (63) & $0.72(0.30-1.29)$ & $0.03(<\mathrm{LOQ}-0.06)$ \\
\hline \multicolumn{3}{|c|}{ Medication before pregnancy } \\
\hline Yes (38) & $0.80(0.33-1.36)$ & $0.03(<\mathrm{LOQ}-0.05)$ \\
\hline No (64) & $0.66(0.28-1.23)$ & $0.03(<\mathrm{LOQ}-0.05)$ \\
\hline \multicolumn{3}{|l|}{ Smoking } \\
\hline Yes (27) & $0.58(0.24-0.88)$ & $0.03(<\mathrm{LOQ}-0.06)$ \\
\hline No $(75)$ & $0.74(0.35-1.34)$ & $0.03(<\mathrm{LOQ}-0.05)$ \\
\hline \multicolumn{3}{|c|}{ Secondhand smoke } \\
\hline Yes (11) & $0.71(0.42-0.88)$ & $<$ LOQ $\left(<\mathrm{LOQ}^{-0.03)}\right.$ \\
\hline No $(85)$ & $0.71(0.29-1.54)$ & $0.03(<\mathrm{LOQ}-0.06)$ \\
\hline
\end{tabular}

Subject number in parenthesis, Median (25-75\%)

\section{Discussion}

The placenta cannot prevent $\mathrm{Pb}$ transfer to the fetus, although the underlying transfer mechanisms remain ambiguous [12]. Ostrea et al [13]. discussed that a fetus can be exposed to different chemicals, most of which are deposited and accumulated in the meconium, and the process occurs through bile secretion and/ or fetal swallowing of amniotic fluid, starting in the 12 th week of gestation.

The primary objective of this study was to consider the possibility/applicability of the assessment of exposure to heavy matals during pregnancy by measuring their concentrations in meconium, which had not previously been reported in Japan. Another purpose was to determine the concentrations of heavy metals in meconium. We found that the consentrations of heavy metals in meconium due to prenatal exposure in Japan were low, although the applicability of meconium as a prenatal exposure marker is still unclear.

Because a method to analyze meconium has not yet been established, in this study we used the method described by Ostrea et al. [1]. We checked the validity of the methods of analysis, such as through recovery tests, the results of which showed that measurement in meconium could be applicable. However, it may be necessary to conduct a number of experiments of blank tests, recovery tests, etc., in the future to increase reliability and validity.

Not many studies using meconium to measure exposure to hazardous chemicals have been conducted. Turker et al. measured contaminants in the meconium of 117 newborns in Turkey using atomic absorption spectrophotometry and reported that the median concentration of $\mathrm{Pb}$ was $46.5 \mu \mathrm{g} / \mathrm{g}$ dry weight (wt) (interquartile range (IQR): $1,399 \mu \mathrm{g} / \mathrm{g}$ dry wt) and that of cadmium was $2.3 \mu \mathrm{g} / \mathrm{g}$ dry wt (IQR $55.6 \mu \mathrm{g} / \mathrm{g}$ dry wt) [9].

Chen measured the concentration of heavy metals in the meconium of 198 infants in Taiwan and found concentrations of $11.69 \pm 2.10 \mathrm{ppb}$ dry wt for $\mathrm{Pb}$ (mean \pm standard deviation), $13.59 \pm 7.65$ ppb dry wt for $\mathrm{Cd}$, and $23.45 \pm 50.5$ ppb dry wt for As [10].

Ostrea et al. measured contaminants in 426 meconium samples from newborns in Manila and reported a median concentration of $35.77 \mu \mathrm{g} / \mathrm{ml}$ for $\mathrm{Pb}$ (detection rate: $26.5 \%$ ) and $13.37 \mu \mathrm{g} / \mathrm{ml}$ for $\mathrm{Cd}$ (detection 
rate: $8.5 \%$ ) [1]. Mercury concentration in meconium has also been measured in several studies, although it was not measured in this study $[1,7,8,10-11,14]$.

The concentrations obtained in this study were about $1 \mathrm{ppb}$ at most. Therefore, it can be said that the concentrations were much lower than those in the previous studies described above. The low concentrations may be attributable to a possible low concentration of heavy metals in the Japanese environment, the fact that the subject mothers may not live in contaminated areas, and the fact that they have not had occupational exposure. Because of the low concentration, it is difficult to consider factors that affect the metal levels. However, the contribution to metal exposure of a mother's lifestyle, such as smoking and dietary habits, etc., may be small in Japan, according to the results of the questionnaire survey.

In this study we did not collect other biological samples, such as cord blood or placenta, etc., because of research restrictions. Therefore, we could not discuss the usefulness of meconium in the evaluation of prenatal exposure compared to other samples. It has been pointed out that the behavior of concentrations in meconium differs from other samples [7]. There is a need for further studies to compare the concentration of heavy metals in other biological samples and to investigate the applicability of meconium for the assessment of exposure to heavy metals during pregnancy.

\section{Conclusion}

We showed the distributions of concentrations of heavy metals in meconium due to prenatal exposure in Japan, and the concentrations were low. However, it is necessary to establish a method for using meconium to evaluate prenatal exposure and to accumulate data in order to figure out the effects of heavy metal exposure on children's health.

\section{Acknowledgement}

The cooperation of the participants and ward nursing staff at Tokai University Hospital is greatly appreciated.

\section{References}

1. Ostrea EM, Morales V, Ngoumgna E, Prescilla R, Tan E, Hernandez E, Ramirez GB, Cifra HL \& Manlapaz ML (2002): Prevalence of fetal exposure to environmental toxins as determined by meconium analysis. Neurotoxicol 23: 329-339

2. Ostrea EM Jr, Bielawski DM, Posecion NC Jr, Corrion M, Villanueva-Uy E, Jin Y, Janisse JJ \& Ager JW (2008): A comparison of infant hair, cord blood and meconium analysis to detect fetal exposure to environmental pesticides. Environ Res 106: 277-283

3. NIH (2004): The National Children's Study. Available: http://www.nationalchildrensstudy.gov/Pages/default. aspx (Feb 28, 2013 access)

4. WHO (2004): Children's Environment and Health Action Plan for Europe. Available: http://www.euro.who.int/en/ who-we-are/policy-documents/childrens-environmentand-health-action-plan-for-europe (Feb 28, 2013 access).

5. Center for Mother and Children's Health and Environment (2006): Mother and Children's Health and Environment (MOCHE) Study. Available: http://www.moche.or.kr/ enhome/. (Feb 28, 2013 access)

6. Ministry of Environment, Government of Japan (2011): The Japan Environment and Children's Study. Available: http://www.env.go.jp/en/chemi/hs/jecs/ (Feb 28, 2013 access)

7. Esteban M \& Castaño A (2009): Non-invasive matrices in human biomonitoring. Environ Int 35: 438-449

8. Ramirez GB, Cruz MC, Pagulayan O, Ostrea E \& Dalisay C (2000): The Tagum study I: analysis and clinical correlates of mercury in maternal and cord blood, breast milk, meconium, and infants' hair. Pediatrics 106: 774-781

9. Turker G, Ergen K, Karakoç Y, Arisoy AE \& Barutcu UB (2006): Concentrations of toxic metals and trace elements in the meconium of newborns from an industrial city. Biol Neonate 89: 244-250

10. Chen MJ (2007): The association between metal concentration in meconium and newborn's development. Master thesis, School of Public Health. Taipei Medical University. Available: http://libir.tmu.edu.tw/handle/ 987654321/4361 (Feb 28, 2013 access)

11. Unuvar E, Ahmadov H, Kiziler AR, Aydemir B, Toprak S, Ulker V \& Ark C (2007): Mercury levels in cord blood and meconium of healthy newborns and venous 
blood of their mothers: Clinical, prospective cohort study. Sci Total Environ 374: 60-70

12. Nashashibi N, Cardamakis E, Bolbos G \& Tzingounis V (1999): Investigation of kinetic of lead during pregnancy and lactation. Gynecol Obstet Invest 48: 158-162

13. Ostrea EM Jr, Matias O, Keane C, Mac E, Utarnachitt R, Ostrea A \& Mazhar M (1998): Spectrum of gestational exposure to illicit drugs and other xenobiotic agents in newborn infants by meconium analysis. J Pediatr 133: 513-515

14. Jiang CB, Yeh CY, Lee HC, Chen MJ, Hung FY, Fang SS \& Chien LC (2010): Mercury concentration in meconium and risk assessment of fish consumption among pregnant women in Taiwan. Sci Total Environ 408: $518-523$ 
日本における胎便を用いた重金属曝露評価法に関する予備的検討

梁 娟實 ${ }^{1}$, 中井 里史 ${ }^{1}$, 小田し抢り ${ }^{2}$ ，西野 廣子 ${ }^{2}$ ，石井 美里 ${ }^{3}$ ，横山 寛子 ${ }^{3}$ ，松木 秀明 ${ }^{3}$

1横浜国立大学 大学院環境情報学府

2 東海大学付属病院 看護部

${ }^{3}$ 東海大学 健康科学部 看護学科

要旨：日本における胎便を用いた胎児期重金属曝露評価法に関して, 予備的検討を行った。被験者は, 2010 年 11 月から 2011 年 3 月の間に東海大学病院に出産のため入院し, 胎便採取に同意した母親の新生览である。本研究 の対象物質は, 鉛 $(\mathrm{Pb})$, カドミウム $(\mathrm{Cd})$, 七素 $(\mathrm{As})$ とし, 分析は, ICP-MS を用いて行った．添加回収試験などの結果 から, 本研究で使用した分析方法で胎便中重金属濃度測定ができることが示された。新生児 102 人から採取された 胎便を分析したところ, $\mathrm{Pb}$ と As の濃度 (中央值) は, それぞれ $0.71 \mathrm{ppb}, 0.03 \mathrm{ppb}$ であった。一方, $\mathrm{Cd}$ 濃度の中央值は定 量限界末満であった．胎児期曝露の曝露評価に用いることができるようにするためには, 今後, 種々の生体試料濃度 を測定し,得られた濃度間の関係を調べることなどが必要となる.

キーワード：小児保健, 胎児期環境曝露, 胎便, 重金属, 新生児.

J UOEH(産業医大誌) 35(2)：129 - 135(2013) 